\title{
Device/prototype production of synthetization of scaffolds the base of fibroin and Aloe barbadensis
}

\author{
Mayra Campista Corteletti $\mathrm{a}^{\mathrm{a}}$, Pablo Prata de Almeida ${ }^{\mathrm{b}}$, Gerlane de Souza Pereira da Costa $^{\mathrm{b}}$, \\ Thalia Henke ${ }^{\mathrm{b}}$ \\ ${ }^{a}$ Multivix Serra - Ensino, Pesquisa e Extensão LTDA, Brasil \\ ${ }^{\mathrm{b}}$ Escola Superior São Francisco de Assis, Brasil \\ *Autor correspondente (mayra.ccorteletti@gmail.com)
}

\section{N F O}

\section{Keyworks}

device

tissue engineering scaffolds

\section{Palavras-chaves}

dispositivo engenharia de tecidos scaffolds

\begin{abstract}
A B S T R A C T
This research established itself as principle the building of a device/prototype specific for synthesis of scaffolds composed of gel Aloe barbadensis Miller and fibroin extracted from cocoons of Bombyx mori, elaborate in favor of the development of equivalents dermo-epidermal. Consisting of an experimental study, with materials selection and related equipment, projection and construction of a prototype aiming at processing on larger scale and the best cost-benefit ratio, making the final product more accessible for those who need.In this way,the development of the device/prototypewas carried outnoting his performance in the process, being necessarythe conducting analyses physicochemical and microbiological of the scaffolds produced.
\end{abstract}

\section{R E S U M O}

Produção de dispositivo/protótipo de sintetização de scaffolds a base de fibroína e Aloe barbadensis Esta pesquisa estabeleceu-se como princípio a edificação de um dispositivo/protótipo específico para síntese de scaffolds compostos por gel de Aloe barbadensis Miller e fibroína extraída de casulos de Bombyx mori, elaborados em prol do desenvolvimento de equivalentes dermo-epidérmico. Consistindo em um estudo experimental, com seleção de materiais e equipamentos afins, projeção e construção de um protótipo visando processamento em maior escala e melhor relação custo-benefício, tornando o produto final mais acessível para os que almejam. Desta forma, o desenvolvimento do dispositivo/ protótipo foi realizado constatando sua atuação no processo, sendo necessário a realização de análises físico-quimícas e microbiológicas dos andaimes produzidos. 


\section{INTRODUCTION}

For centuries mankind always sought to understand the components and the constitution of the human body, as results of these efforts numerous advances have occurred in several fields of medicine, new discoveries emerged and creations of new techniques to treat diseases and injuries that reach us throughout life, highlighting the capacity to perform organ and tissue transplants, that enabled and enables until the current days save life of millions of people around the world. However, although it is an effective method, still presents some complications, as rejection occasioned by the receiver after transplantation even with the use of immunosuppressants and including also low availability of organs and tissues available for donation.

Thinking of the countless challenges encountered, over the years the possibilities have multiplied and opened the doors for a new age: the age of biotechnology, with great emphasis on tissue engineering, in which enables new methods of treatments and different forms to circumvent and overcome the obstacles imposed.

Consisting of a method of great potential to be applied in regenerative medicine as a way of treatment for some injuries or diseases in which other methods of treatment are inefficient (Rodrigues, 2012),the tissue engineering consists of in the insatiable search of mastering completely the ability to repair, restore or regenerate degenerated tissues, having as a challenge the systematization of a tissue using a combination of cellular source in consonance with a threedimensional model named scaffold, beyond the addition of signals that stimulate their development (Yildirimer et al., 2012; Cham e Leong, 2008).

The strategy used by in vitro tissue engineering in culture protocols or when applied in situ to repair or regenerate a damaged tissue, consists of perform a cell biopsy obtained of the patient himself, which then are isolated and proliferated in culture systems where they are seeded about scaffolds, being subsequently implanted in the lesion to form a homogeneous tissue with the surrounding tissue, aiming to promote the complete regeneration, avoiding contraction of the wound bed and preventing an inflammatory and toxic response, allowing its application in the patient without major risks of rejection, showing great potential for medical treatments (Moroni e Elisseeff, 2008; Sachlos e Czernuska, 2003; Polak, 2010).

Scaffolds are three-dimensional structures consisting of biomaterials that can be of synthetic or natural origin, having as principle resemble to the maximum with the extracellular matrix, morphologically and physiologically, aiming to achieve an interaction with the native environment promoting tissue development in a successful way, assigning themselves to a series of structural requirements directly linked to migration, cell proliferation and differentiation (Turnbul et al., 2018; Zhang et al., 2014).

But so that certain scaffolds become clinically and commercially available, they should be profitable and possess increased production scales, being directly related with the processing method applied and materials used, taking into consideration the definition of how the final product will be delivered and made available to the market, as well as your storage (O'Brien , 2011; Ahsan et al., 2005).

There are a wide range of scaffolds processing methods, operating with distinctive characteristics and some specifications limiting them to work with certain classes of biomaterials. Therefore, the development of technologies with higher processing rates and cost reduction, beyond the search for materials with better physicochemical properties are of great interest to the sector (Chan e Mooney, 2008; Vunjak-Novakovic e Kaplan, 2006).

Fibroin has numerous characteristics desirable for application in tissue engineering due to its biocompatibility, low immunogenicity, bacterial adhesion limited and tunable biodegradability. Possessing approval by FDA, silk is one of the best natural biopolymers for dressings (Turnbull et al., 2018; Peter, 2004).

Biocompatibility of materials consisting of silk fibroin is well approved when applied in tissue engineering, as studies demonstrate that after its subcutaneous implantation in rats feature low immune response, being that associated genes immune response as TNF- $\alpha$, IFN- $\delta$, IL- 4 , IL- 6 e IL13 , are kept in undetectable expression levels (Ma et al., 2018).

Evaluating the current level of tissue engineering and seeking to propose new alternatives, the present work has for objective the building of a device for synthesis of scaffolds consisting mainly by Fibroin and gel of Aloe barbadensis Miller.

\section{MATERIALS AND METHODS}

This is an experimental study through a new methodologythat account in the elaboration of a device/ prototype directed to synthesis of scaffolds consisting primarily the base of fibroin, Aloe barbadensis Miller gel incremented with other specific compounds for cutaneous tissue homeostasis, aiming at a higher productivity scale, 
best relationship of cost-benefit and practicality of operation.

The present device/ prototype idealized has as principle the development of operational complexes with capacities to act in the total removal of Sericin extracted from cocoons of Bombyx mori keeping up to the fullest its molecular structures, with the intension of obtain Fibroin plates, that subsequently through a sandblasting complex could be unified with an incremented solution of Aloe barbadensis Miller.

After initial idealization, emphasized the elaboration of three-dimensional projective designs characteristic of each portion, with markers and geometric orientations, measures, angles and connector parts, directing your assembly order, morphologic aspects and structural distributions through typical calculations, contributing directly for its materialization.

Concentrating on the development of the prototype in a way economically viable and in a manner that would allow assess the hypotheses about its functionalities and applications, through selection of equipment and related materials, for example: micro engines Dc 12 and $15 \mathrm{~V}$, power supplies, push- buttons, interrupter keys, electrical connectors, micro suction pump, siliconized hoses, flexible spiral conduits, pulleys, ratchets, PVC pipes, aluminum rails and shafts, screens, colorless plastic boxes, light board, valves, plywood for the development of the structural base, distributing and unifying the selected materials in specific positions determined according to initial planning.

In this way, aiming the building of a prototype initially non-automated, able to act at all stages in the course of the procedure, whose controls of operation were determined manually through the activation of push- buttons and interrupter keys.

\section{RESULTS AND DISCUSSION}

Through the initial idealization carried out the three-dimensional projective drawing's characteristic of each portion, which have established the principle for building the device that was set in three complexes with different functionalities for synthesis of scaffolds.

With proper materials and selected equipment, the development of the prototype was achieved, consisting of a rinse complex post-removal of sericin, drying platform of fibroin plates and blasting platform, together forming the scaffolds synthesis device, outlined in figure 1 .

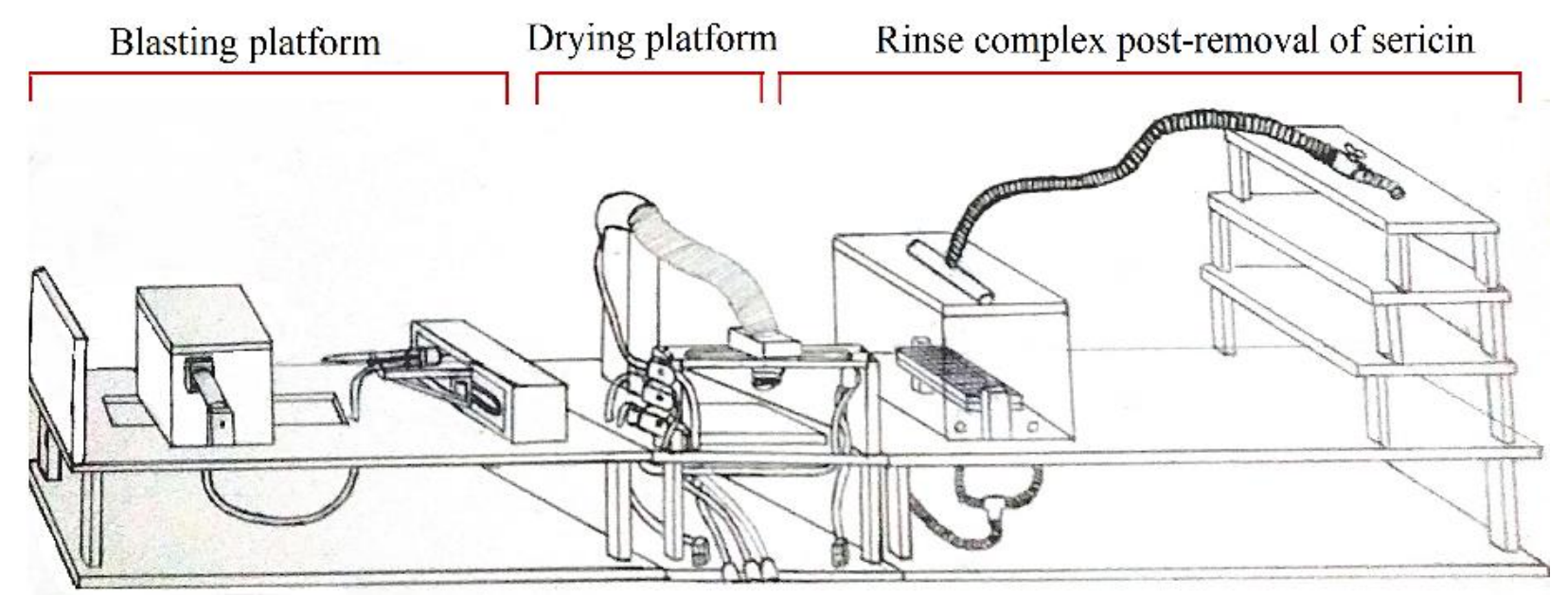

Figure 1 - Scaffolds synthesis device.

The rinse complex post-removal of sericin was obtained starting with the construction of a dual base support through plywood, where all the functional components were attached and elaborated according to the stages of the procedure.

Initially for sericin removal of the cocoons without profoundly altering its molecular properties and its fibrous structure, for that purpose developed a retaining plate consisting of two rectangular frames, where the containment screens were adapted allowing the pressing of the cocoons during the removal of Sericin immersed in a water bath solution. The two plates were joined together through an axis enabling its opening for organizing the cocoons inside, in addition to a scheme locking and coupling in its rotating structure during the rinse process.

Finalized the process of removal of sericin, to perform the rinse of the fibroin plates with the purpose of removing the residues from the procedure applied, the retaining plate was built so that enable the coupling to a support structure by constituting on lifting brackets with shafts and connection to a micro engine responsible for 
rotation of the plate during processing.

The rotating structure of the retaining plate, has been adapted inside a plastic box, being on your lid installed a horizontal shower responsible by targeting of water in microjets over the fibroin structures retained on the rotating plate, occasioning its rinsing on both surfaces in a way that would not damage Its fibrous structure. The water is provided from an external source reaching to the shower through siliconized Hose and evacuated through flow holes gifts on background of box coupled to flexible spiral conduits that disposes in the appropriate place.

Before the blasting phase, the fibroin structures undergo some processes for plate formation, one of them is the drying process, carried out through the development of quick-drying platform by heated air flow, with objective of the moisture removal present in the fibroin plates.

The device is designed through the construction of a main plywood base, serving of support for all functional structures, consisted of an elaborate scheme of rails, pulleys, belts, ratchet, axles and micro engine, powered by voltage specific power supplies, that by means of reversing load directs engine rotation directing the horizontal movement of a spiralized flexible conduit, possessing its initial portion adapted into a source of heated air, being the opposite end fixed to a sliding car attached to the rail, making air flow shock with the entire surface area of the fibroin plates enabling its drying.

For the unification of the fibroin plates with the manipulated solution and incremented of Aloe barbadensis Miller gel, the blasting platform was built. Consisting of a main support base, on which it was annexed the functional components of the device.

At one end of the support base, adapted a light board, focused on a retaining box possessing in its frontal part a rectangular clipping for jet passage from the blasting complex, colliding with the collector cylinder present in its Inside.

The collector cylinder present inside the box has constant rotation, which is accomplished by a motor coupled to a set of gears attached to a horizontal axis that crosses the center of the cylinder coupling to support bracket opposite the engine. Being responsible for contain the fibroin plates on its surface, pinned by means of grids that have rectangular holes, acting as retention grooves the measure that the cylinder rotates and the solution is absorbed by the material.

Realized in the background of the retention box, installed in a sloping manner towards its frontal portion, a flow hole connects to a siliconized hose connected to a suction pump directing the flow through an outlet hose coupled to a beak with flow orifice pre-established according to the variation, decline and bifurcation of the jet toward the collector, that through this system maintains a cyclical flow during blasting.

The suction pump was positioned on a horizontal motion platform attached in a rail system, pulleys, belts, axes, ratchets, and engine controlled by specific power supplies, being the directing of the blasting beak determined by the inversion of load by means of push-buttons, allowing the jet be directed over the entire surface of the cylindrical collector.

Therefore, after the construction of the device/prototype, through synthesis tests, he observed that it was able to act in the production of scaffolds as planned. However in-depth tests are necessary to determine their effectiveness.

\section{CONCLUSION}

For all these aspects, the desired objectives were achievedthrough the development of the device/prototypefor synthetization of scaffolds the base of fibroin and Aloe barbadensis Miller gel, verifying its functionality of action in the process.However, it becomes necessary the conducting analyses physicochemical and microbiological of the scaffolds produced to evaluate and track the structuring and modifications occurred throughout the process in addition to quantifying an average regarding its constitution.

\section{REFERENCES BIBLIOGRAPHICAL}

Ahsan T, Nerem RM. Bioengineered tissues: the science, the technology, and the industry. Orthodontic \& Craniofacial Clinical and Translational Research. v.8, n.3, p134-140, 2005.

https://doi.org/10.1111/j.1601-6343.2005.00326.x

Chan BP, Leong KW. Scaffolding in tissue engineering: general approaches and tissue-specific considerations. European Spine Journal. v.17, n.4, p467-479, 2008. https://doi.org/10.1007/s00586-008-0745-3

Chan G, Mooney DJ. New materials for tissue engineering: towards greater control over the biological response. Trendsin Biotechnology. v.26, n.7, p382-392, 2008. https://doi.org/10.1016/j.tibtech.2008.03.011

Ma D, Wang Y, Dai W. Silk fibroin-based biomaterials for musculoskeletal tissue engineering.Materials Science and Engineering. v.89, n.1, p456-469, 2018. https://doi.org/10.1016/j.msec.2018.04.062

Ma PX. Scaffolds for tissue fabrication. Materials Today. v.7, n.5, p30-40, 2004.

https://doi.org/10.1016/S1369-7021(04)00233-0 
Moroni L, Elisseeff JH. Biomaterials engineered for integration. Materials Today. v.11, n.5, p44-51, 2008.

https://doi.org/10.1016/S1369-7021(08)70089-0

O'Brien FJ. Biomaterials \& scaffolds for tissue engineering. Materials Today. v.14, n.3, p88-95, 2011. https://doi.org/10.1016/S1369-7021(11)70058-X

Polak DJ. Regenerative medicine. Opportunities and challenges: a brief overview. Journal of the Royal Society. v.7, n.6, p777-781, 2010. https://doi.org/10.1098/rsif.2010.0362.focus

Rodrigues BFFS. Engenharia de tecidos para regeneração da pele: retrospectiva e perspectivas futuras. Ano de obtenção: 2012. 68p. Dissertação (Mestrado Integrado em Ciências Farmacêuticas) - Universidade Fernando Pessoa, Porto.

Sachlos E, Czernuszka JT. Making Tissue Engineering Scaffolds Work. Review: The application of solid freeform fabrication technology to the production of tissue engineering scaffolds. v.5,p29-40, 2003.

https://doi.org/10.22203/eCM.v005a03

Turnbull G, Clarke J, Picard F, Riches P, Jia L, Han E, Li B, Shu W. 3D bioactive composite scaffolds for bone tissue engineering. Bioactive Materials. v.3, n.3, p278-314, 2018. https://doi.org/10.1016/j.bioactmat.2017.10.001

Vunjak-Novakovic G, Kaplan DL. Tissue Engineering: The Next Generation. Tissue Engineering. v.12, n.12, p.32613263, 2006

https://doi.org/10.1089/ten.2006.12.3261

Yildirimer L, Thanh NTK, Seifalian AM. Skin regeneration scaffolds: a multimodal bottom-up approach. Trends in Biotechnology. v.30, n.12, p.638-648, 2012. https://doi.org/10.1016/j.tibtech.2012.08.004

Zhang Z, Gupte MJ, Ma PX. Biomaterials and stem cells for tissue engineering. v.13, n.4, p.527-540, 2013.

https://doi.org/10.1517/14712598.2013.756468 